\title{
Oral Health Profile in Patients Infected With HTLV-1: Clinical Findings, Proviral Load, and Molecular Analysis From HTLV-1 in Saliva
}

\author{
Liliane Lins, ${ }^{1,2}$ Victor José Uchoa de Carvalho, ${ }^{1,3}$ Filipe Ferreira de Almeida Rego, ${ }^{1,3}$ \\ Rochele Azevedo, ${ }^{4}$ Simone Kashima, ${ }^{4}$ Viviana Nilla Olavarria Gallazi, ${ }^{1,3}$ Marcia Tosta Xavier, ${ }^{1}$ \\ Bernardo Galvão-Castro, ${ }^{1,3}$ and Luiz Carlos Junior Alcantara ${ }^{1,3} *$ \\ ${ }^{1}$ Bahiana School of Medicine and Public Health, Salvador, Bahia, Brazil \\ ${ }^{2}$ Federal University of Bahia-UFBA School of Medicine, Salvador, Bahia, Brazil \\ ${ }^{3}$ Gonçalo Moniz Research Center, Oswaldo Cruz Foundation, Salvador, Bahia, Brazil \\ ${ }^{4}$ National Institute of Science and Technology in Stem Cells and Cell Theraphy, \\ University of São Paulo-USP School of Medicine, Ribeirao Preto, São Paulo, Brazil
}

Human T-lymphotropic virus type 1 (HTLV-1) is associated with adult T-cell leukemia (ATL) and HTLV-1 associated myelopathy/tropical spastic paraparesis (HAM/TSP) and has also been implicated in several disorders, including periodontal disease. The proviral load is an important biological marker for understanding HTLV-1 pathogenesis and elucidating whether or not the virus is related to the clinical manifestation of the disease. This study describes the oral health profile of HTLV-1 carriers and HAM/TSP patients in order to investigate the association between the proviral load in saliva and the severity of the periodontal disease and to examine virus intra-host variations from peripheral blood mononuclear cells and saliva cells. It is a cross-sectional analytical study of 90 individuals carried out from November 2006 to May 2008. Of the patients, 60 were HTLV-1 positive and 30 were negative. Individuals from the HTLV-1 positive and negative groups had similar mean age and social-economic status. Data were analyzed using two available statistical software packages, STATA 8.0 and SPSS 11.0 to conduct frequency analysis. Differences of $P<0.05$ were considered statistically significant. HTLV-1 patients had poorer oral health status when compared to seronegative individuals. A weak positive correlation between blood and saliva proviral loads was observed. The mean values of proviral load in blood and saliva in patients with HAM/TSP was greater than those in HTLV-1 carriers. The HTLV-1 molecular analysis from PBMC and saliva specimens suggests that HTLV- 1 in saliva is due to lymphocyte infiltration from peripheral blood. A direct relationship between the proviral load in saliva and oral manifestations was observed. J. Med. Virol. 84:14281436, 2012. ๑ 2012 Wiley Periodicals, Inc.

KEY WORDS: oral health; saliva; HTLV-1

\section{INTRODUCTION}

Human T-lymphotropic virus type 1 (HTLV-1) was the first human retrovirus described [Poiez et al., 1980]. HTLV-1 is endemic in Southwestern Japan, Melanesia, Caribbean Islands, Central and South America, as well as in parts of Africa. It has been estimated that 20 million people are infected worldwide [Catalan-Soares et al., 2001; Proietti et al., 2005]. Salvador, the capital city of the State of Bahia located in Northeastern Brazil, has the highest described prevalence of HTLV-1 in Brazil. A cross-sectional population-based study carried out in Salvador found a prevalence of HTLV-1 infection of $1.7 \%$, estimating that approximately 50,000 individuals were infected

Grant sponsor: FAPESB; Grant number: 303/03; Grant sponsor: Brazilian Ministry of Health; Grant numbers: 306/04. 307/04.

This paper is a part of the Master Dissertations of V.J.U.C. and F.F.A.R.

Liliane Lins and Victor José Uchoa de Carvalho contributed equally to this study.

*Correspondence to: Luiz Carlos Junior Alcantara, Gonçalo Moniz Research Center, Oswaldo Cruz Foundation, Rua Waldemar Falcão 121, Candeal, Salvador, Bahia 40296-610, Brazil.

E-mail: lalcan@bahia.fiocruz.br

Accepted 24 April 2012

DOI 10.1002/jmv.23327

Published online in Wiley Online Library

(wileyonlinelibrary.com). 
by this retrovirus [Dourado et al., 2003]. Another survey carried out in the city reported that $0.45 \%$ of blood donors had HTLV-1 infection [Mota et al., 2006]. In an earlier study, a prevalence of $1.35 \%$ had been found in the same group, suggesting an apparent decrease in the infection in blood donors over the last decade in Salvador [Galvão-Castro et al., 1997]. HTLV-1 is associated with adult T-cell leukemia (ATL) [Poiez et al., 1980] and HTLV-1 associated myelopathy/tropical spastic paraparesis (HAM/TSP) [Gessain et al., 1985; Osame et al., 1985] and has also been implicated in several disorders, such as uveitis [Mochizuki et al., 1996], Sjögren's syndrome [Nakamura et al., 2000], polymyositis [Cruz et al., 2005], and infective dermatitis [La Grenade et al., 1998].

Although the scientific literature correlates Sjögren syndrome with HTLV-1, this association is unclear. Some authors suggest that the association of IgA anti-HTLV-1 in saliva of patients with Sjogren's syndrome is more common than in saliva of patients with HAM/TSP or HTLV-1 carriers [Terada et al., 1994]. Although the virus has been isolated from lymphocytes present in saliva of infected patients, HTLV-1 transmission is not feasible in this way due to the low concentration of the virus in saliva, as well as the presence of neutralizing antibodies as salivary IgG [Yamamoto et al., 1995]. It is noteworthy that leukocytes found in whole saliva, including lymphocytes, represent only a very tiny proportion of those found in blood [Jorge, 1998].

HTLV-1 sequences were detected in salivary gland tissue from patients with HAM/TSP as well in seropositive patients without neurological disease. In this report, HTLV-1 proviral DNA was detected by the polymerase chain reaction (PCR) amplification in DNA extracted from lip biopsies of every patients. Virus RNA was detected by in situ hybridization in acini epithelium, as well as in lymphocytic infiltrates. The authors suggest that the presence of HTLV-1 tax sequence expression in salivary glands could participate in the inflammatory lesions observed in infected patients [Tangy et al., 1999]. European investigators have also detected the HTLV-1 tax gene in biopsy specimens of salivary glands from patients with Sjögren's syndrome and other inflammatory processes. The gene was detected in biopsy specimens of salivary glands in 15 out of the 50 patients with Sjögren's syndrome. The study also showed the presence of this gene in 9 out of 32 patients with other inflammatory diseases involving salivary glands, such as graftversus-host disease, sarcoidosis, and extravasated cysts, and from only 1 out of 26 patients with normal salivary glands [Mariette et al., 2000].

A Brazilian survey of patients infected with HTLV1 was conducted in Salvador, Bahia, associating periodontal diseases, stomatitis, and dry mouth with the virus infection [Giozza, 2006]. It has been suggested that the HTLV-1 infection may be implicated in periodontal disease due to the altered levels of cytokines
[Garlet et al., 2010]. Iinfection with HTLV-1 promotes an exacerbated inflammatory immune response, possibly associated with an impaired Treg activity in response to a usual pattern of periodontal infection.

Proviral load is an important biological marker to understand HTLV-1 pathogenesis and to elucidate whether or not the virus is related to the clinical manifestation of the disease. HAM/TSP individuals usually have a higher proviral load when compared to asymptomatic ones [Haddad, 2004; Yakova et al., 2005]. The association between rheumatoid arthritis, as well as Sjögren's syndrome, with HAM/TSP has been described [Ferraz-Chaoui et al., 2010]. There are few studies evaluating oral disease in HTLV-1infected patients.

This study aimed to describe the oral heath profile of HTLV-1 carriers (no-HAM/TSP) and HAM/TSP patients, to investigate the association between the proviral load in saliva and the severity of periodontal disease and to analyze virus intra-host variations from peripheral blood mononuclear cells (PBMC) and saliva cells from persons infected with HTLV-1.

\section{MATERIALS AND METHODS}

\section{Study design and population}

This cross-sectional analytical study was conducted at the Integrative and Multidisciplinary Center for HTLV at the Bahiana School of Medicine and Public Health (EBMSP), Salvador, Bahia, Brazil. Ninety individuals, 65 females (72\%), participated in this survey from November 2006 to May 2008. Of the patients, 60 were HTLV-1 positive and 30 were negative. Individuals from the HTLV-1 positive and negative groups had similar mean age and social-economic status. The diagnosis of HAM/TSP was determined according to WHO guidelines [Osame, 1990]. The study protocols were approved by the Ethical Review Board from EBMSP, under protocol number 28/2006, respecting the Brazilian Health National Council Resolution 196/96, as well as the Helsinki Declaration, 2008. All the volunteers provided written informed consent before sharing the research protocol.

\section{Laboratory, Clinical, and Stomatological Diagnosis}

Before clinical examination, $3 \mathrm{ml}$ of saliva were collected from the HTLV positive patients in a sterile plastic centrifuge tube of $50 \mathrm{ml}$ and frozen $\left(-70^{\circ} \mathrm{C}\right)$ for subsequent detection of proviral load in saliva. In order to quantify the proviral load in peripheral blood, $10 \mathrm{ml}$ of peripheral blood was collected in tubes containing EDTA for PBMC isolation by density gradient using the Ficoll-Hypaque technique.

All patients were examined for their oral health in accordance with standards established by the World Health Organization for periodontal disease [WHO, 1999]. The following parameters were evaluated: 
clinical attachment loss (CAL), probing pocket depth (PPD), tooth mobility, and DMFT index represented as the number of decayed/missing/filled teeth. A salivary flow test was conducted [Krasse, 1998; Thylstrup and Fejerskov, 2001] and a flow of saliva between 1 and $3 \mathrm{ml} / \mathrm{min}$ was classified as normal while less than $1 \mathrm{ml} / \mathrm{min}$ was considered to be reduced.

Genomic DNA from PBMCswas extracted using a commercially available kit, QIAamp DNA Blood Kit (Qiagen, Valencia, CA), and measured by spectrophotometry. DNA extraction in saliva followed a similar technique used for PBMCs, except that each milliliter of saliva was mixed with $4 \mathrm{ml}$ of PBS ( $\mathrm{pH} 7.1$ ) and centrifuged at room temperature for $5 \mathrm{~min}$ at $1,700 \mathrm{~g}$. The precipitate was resuspended in $180 \mu$ l of PBS after the supernatant had been discarded. The proviral load of HTLV-1 in PBMC was determined by quantitative real-time PCR, using $10^{6} \mathrm{PBMC}$ and the albumin gene as an endogenous human genomic control. The quantitation of proviral DNA was calculated by the number of copies of the HTLV- 1 per $10^{6}$ cells as previously described [Dehee et al., 2002]. The HTLV-1 proviral load in the saliva was quantified using the DNA from saliva and the result was given as the number of copies of HTLV in $3 \mathrm{ml}$ of saliva. The molecular biology studies were performed at the Gonçalo Muniz Research Center (CPqGM)/Oswaldo Cruz Foundation, Bahia (FIOCRUZ/BA).

DNA from PBMCs was submitted to a nested-PCR with specific primers for the long-terminal repeat (LTR) genomic region of HTLV. The tax-LTR segment of $479 \mathrm{bp}$ was amplified to HTLV-1 as previously described [Alcantara et al., 2006], and all PCR products were purified using the QIAGEN PCR purification Kit.

Molecular cloning. From the PCR positive samples, molecular cloning was performed using TOPO TA Cloning ${ }^{\mathbb{R}}$ Kit following the manufacturer's instructions, and at least 10 colonies of each sample were selected for DNA isolation from plasmids by Wizard ${ }^{\circledR}$ Plus SV Minipreps DNA Purification System (Promega, Madison, WI). From isolated DNA, an enzymatic reaction with the EcoRI enzyme was performed to verify the insert presence. DNA was sequenced from plasmids using the Taq FS Dye terminator cycle sequencing kit (Applied Biosystems, Foster City, CA) using an automated 3100 genetic analyzer (Applied Biosystems Inc.), with the same inner primers.

Molecular analysis. The new LTR sequences were aligned using the ClustalX software [Thompson et al., 1997], and manually edited using the GeneDoc [Nicholas et al., 1997] program. Phylogenetic analysis was performed using the maximum-likelihood (ML) and neighbor-joining (NJ) methods of PAUP*, version 4.0b.10 [Swofford, 1998]. The Hasegawa-KishinoYano (HKY) evolutionary model (which takes into account variable base frequencies and variable transition and transversion frequencies) was selected by Modeltest 3.7 software [Posada and Crandall, 1998]. The reliability of the $\mathrm{NJ}$ trees was assessed by analyzing 1,000 bootstrap replicates. For ML trees, a heuristic search was performed with a subtreepruning-regrafting branch swapping algorithm including its optimized parameters. Trees were drawn with FigTree version 1.3.1 (available at http://tree. bio.ed.ac.uk/software).

To analyze the presence of one post-translational modification sites profile at PBMC and mouthwash cells, the tax fragment was translated by GeneDoc software and the protein sequences were submitted to the Prosite tool in the GeneDoc software. The nonparametric test for panmixia, Hudson test, was performed to analyze the mean pairwise difference $\left(K_{s}\right)$ and the mean pairwise $\log \left(\mathrm{K}^{*} \mathrm{~s}\right)$ within each sample to verify the HTLV-1 clonal profile between PBMC and mouthwash cells. The results were significant if $P<0.005$. Means of the genetic distances within the HTLV-1 clones were measured using the Kimura 2-parameter substitution model, implemented in Mega3 software [Kumar et al., 1994].

\section{Statistical Analysis}

Two available statistical software packages, STATA 8.0 and SPSS 11.0, were used to carry out frequency analysis. The chi-squared test was used to verify proportion and prevalence ratio differences, as well as Fisher's exact test $(\mathrm{CI}=95 \%)$. In order to compare means of age and DMFT between the seropositive and seronegative groups, the $t$-test was used and logistic regression was performed to investigate the association between proviral load in saliva and depression or HAM/TSP, controlling for the relevant covariable. Differences of $P<0.05$ were considered statistically significant.

\section{RESULTS}

The socio-demographic profile of both groups, HTLV-1 positive and negative (Table I) showed a predominance of females ( $78.3 \%$ and $60 \%$, respectively), aged $31-50$ years $(60 \%$ and $46.7 \%)$, low income (48.3\% and $43.3 \%$ ), and education (58.3\% and $46.7 \%$ ). Both groups had a high prevalence of cariogenic food intake (83.3\% and $76.7 \%$, respectively). All risk factors for the acquisition of HTLV-1 such as the use of injectable drugs, sexually transmitted diseases, unprotected sex and multi-partner sex were similar in both groups, except blood transfusion which was more frequent in the seropositive group (25\%) than in negative one $(6.6 \%)$.

\section{Oral health evaluation}

The main clinical complaints related to oral health (sensation of dry mouth, dysphagia, and ocular dryness) were more frequent among individuals from the HTLV-1 positive group (Table II). The agreement between the individual perception of dry mouth and hyposalivation, as measured by the siaolometric test 
TABLE I. Socio-Demographic Characteristics and Cariogenic Diet of HTLV-1 Positive and Negative Groups

\begin{tabular}{|c|c|c|c|c|c|}
\hline \multirow[b]{3}{*}{ Variables } & \multicolumn{5}{|c|}{ HTLV-1 } \\
\hline & \multicolumn{2}{|c|}{ Positive $(\mathrm{n}=60)$} & \multicolumn{2}{|c|}{ Negative $(\mathrm{n}=30)$} & \multirow[b]{2}{*}{$P$-value } \\
\hline & $\mathrm{N}$ & $\%$ & $\mathrm{~N}$ & $\%$ & \\
\hline Age mean (SD) in years & 42.1 & 13.0 & 36.9 & 13.1 & 0.080 \\
\hline Sex & & & & & 0.083 \\
\hline Female & 47 & 78.3 & 18 & 60.0 & \\
\hline Male & 13 & 21.7 & 12 & 40.0 & \\
\hline \multicolumn{6}{|l|}{ Age (years) } \\
\hline $18-30$ & 11 & 18.3 & 10 & 33.3 & \multirow{3}{*}{0.273} \\
\hline $31-50$ & 36 & 60.0 & 14 & 46.7 & \\
\hline$>50$ & 13 & 21.7 & 6 & 20.0 & \\
\hline \multicolumn{5}{|l|}{ Skin color (self-identified) } & \multirow[t]{3}{*}{0.452} \\
\hline White & 17 & 28.3 & 6 & 20.0 & \\
\hline Not White & 43 & 71.7 & 24 & 80.0 & \\
\hline \multicolumn{5}{|l|}{ Education (years) } & \multirow{3}{*}{0.367} \\
\hline$\leq 8$ & 35 & 58.3 & 14 & 46.7 & \\
\hline$>8$ & 25 & 41.7 & 16 & 53.3 & \\
\hline \multicolumn{5}{|l|}{ Income } & \multirow[t]{4}{*}{0.695} \\
\hline$<1 \mathrm{MW}$ & 29 & 48.3 & 13 & 43.3 & \\
\hline$=1 \mathrm{MW}$ & 22 & 36.7 & 9 & 30.0 & \\
\hline$\geq 2 \mathrm{MW}$ & 9 & 15.0 & 8 & 26.7 & \\
\hline \multicolumn{5}{|l|}{ Cariogenic diet } & \multirow[t]{3}{*}{1.000} \\
\hline Yes & 50 & 83.3 & 23 & 76.7 & \\
\hline No & 10 & 16.7 & 7 & 23.3 & \\
\hline
\end{tabular}

SD, standard deviation; MW, minimum wage, approximately US\$ 345.00.

was $67.7 \%$ (kappa $=0.326 ; P=0.002)$. The agreement between complaints of dryness of the mucus membrane and hyposalivation 56.6\% (kappa $=-0.15$, $P=0.828)$ and between xeroftalmy and hyposalivation $55.5 \%$ (kappa $=0.001, P=0.995)$ was poor.

Oral health status, as measured by mean DMTF was higher in the HTLV-1 positive group (21) than in the negative group (16.4). On stratifying mean DMFT by gender and HTLV-1 infection, it was observed that mean DMFT was higher in the HTLV-1 positive group, regardless of gender (mean values of 21 and 22 , for positive females and males, respectively, whereas the mean DMFT were 13 and 18 for females and males in the negative group).

The relative proportions of complaints of dry mouth, decreased salivary flow, periodontal disease, and gingival attachment loss were higher in the HTLV-1 positive group. Although tooth mobility was higher in seropositive group, it was not statistically significant (Table III).

Pathological findings of oral lesions were more frequent among individuals from the HTLV-1 positive group. Stomatitis, abscess, and fistula were positively associated with HTLV-1 infection $(\mathrm{PR}=2.87,95 \%$

TABLE II. Clinical Complaints From Individuals From HTLV-1 Positive and Negative Groups

\begin{tabular}{|c|c|c|c|c|c|}
\hline \multirow[b]{3}{*}{ Variables } & \multicolumn{5}{|c|}{ HTLV-1 infection } \\
\hline & \multicolumn{2}{|c|}{ Positive $(\mathrm{n}=60)$} & \multicolumn{2}{|c|}{ Negative $(\mathrm{n}=30)$} & \multirow[b]{2}{*}{$P$-value } \\
\hline & $\mathrm{N}$ & $\%$ & $\mathrm{~N}$ & $\%$ & \\
\hline Oral burning symptoms & & & & & 0.463 \\
\hline Yes & 6 & 10.0 & 2 & 6.7 & \\
\hline No & 54 & 90.0 & 28 & 93.3 & \\
\hline Prosthesis retention difficulties & & & & & 0.457 \\
\hline Yes & 4 & 6.7 & 1 & 3.3 & \\
\hline No & 56 & 93.3 & 29 & 96.7 & \\
\hline Dysphagia & & & & & 0.027 \\
\hline Yes & 9 & 15.0 & 0 & 0.0 & \\
\hline No & 51 & 85.0 & 30 & 100.0 & \\
\hline Dry mouth & & & & & 0.020 \\
\hline Y̌es & 28 & 46.7 & 6 & 20.0 & \\
\hline No & 32 & 53.3 & 24 & 80.0 & \\
\hline Dry eyes & & & & & 0.046 \\
\hline Yes & 15 & 25.0 & 2 & 6.7 & \\
\hline No & 45 & 75.0 & $2 \overline{8}$ & 93.3 & \\
\hline
\end{tabular}


TABLE III. Oral Health Profile of Individuals From HTLV-1 Positive and Negative Groups

\begin{tabular}{|c|c|c|c|c|c|}
\hline \multirow[b]{3}{*}{ Variables } & \multicolumn{5}{|c|}{ HTLV-1 infection } \\
\hline & \multicolumn{2}{|c|}{ Positive $(\mathrm{n}=60)$} & \multicolumn{2}{|c|}{ Negative $(\mathrm{n}=30)$} & \multirow[b]{2}{*}{$P$-value } \\
\hline & $\mathrm{N}$ & $\%$ & $\mathrm{~N}$ & $\%$ & \\
\hline \multicolumn{6}{|l|}{ Dry mouth } \\
\hline Yes & 28 & 46.7 & 6 & 20.0 & 0.020 \\
\hline No & 32 & 53.3 & 24 & 80.0 & \\
\hline \multicolumn{6}{|l|}{ Salivary flow } \\
\hline Normal & 30 & 50.0 & 23 & 77.0 & 0.025 \\
\hline Reduced & 30 & 50.0 & 7 & 23.0 & \\
\hline \multicolumn{6}{|l|}{ Dental mobility $^{\mathrm{a}}$} \\
\hline Yes & 19 & 33.3 & 4 & 14.3 & 0.074 \\
\hline No & 38 & 66.7 & 24 & 85.7 & \\
\hline \multicolumn{6}{|l|}{ Periodontal disease $^{a}$} \\
\hline No disease & 0 & 0.0 & 1 & 3.6 & 0.008 \\
\hline Gingivitis & 21 & 36.8 & 18 & 64.3 & \\
\hline Periodontitis & 36 & 63.2 & 9 & 32.1 & \\
\hline \multicolumn{6}{|c|}{ Gingival attachment loss ${ }^{\text {a }}$} \\
\hline $0-3 \mathrm{~mm}$ & 25 & 43.9 & 20 & 71.4 & 0.021 \\
\hline$>4 \mathrm{~mm}$ & 32 & 56.1 & 8 & 28.6 & \\
\hline DMTF (mean \pm SD) & \multicolumn{2}{|c|}{$21 \pm 5.4$} & \multicolumn{2}{|c|}{$16.4 \pm 7.6$} & 0.006 \\
\hline
\end{tabular}

DMFT index, decayed, missing, and filled teeth.

aThe " $n$ " for analysis of these variables were respectively 57 and 28 , whereas excluded patients were edentulous.

CI: $1.09-7.56)$. Reduced salivary flow $(\mathrm{PR}=2.14,95 \%$ CI: $1.07-4.30)$ and periodontitis (PR $=1.96,95 \% \mathrm{CI}$ : 1.11-3.49) were more prevalent among individuals from the HTLV-1 positive group.

\section{HTLV-1 Positive Group Analysis}

The proviral load from the blood and saliva of the individuals from the HTLV-1 positive group showed a weak positive correlation between blood and saliva proviral loads $(\mathrm{R}=0.28, \quad P=0.04 ; \quad$ Fig. 1$)$. The amount of the virus in saliva $(0.02-6.00$ copies of

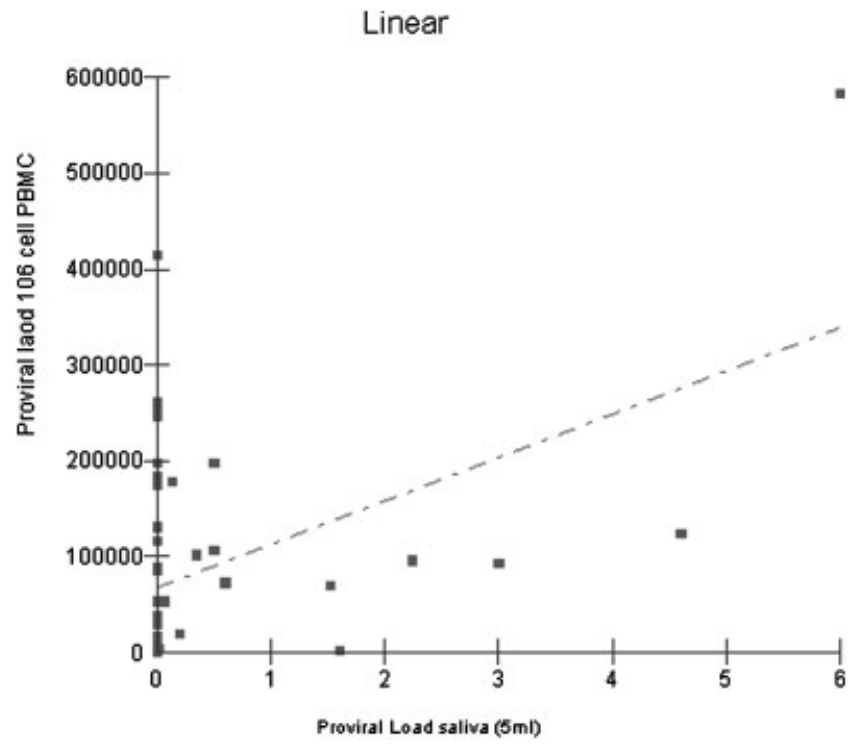

Fig. 1. Correlation of proviral load in PBMC and saliva in HTLV1 positive individuals.
HTLV pol gene $/ 3 \mathrm{ml}$ of saliva) was lower than the quantity detected in the blood (633.0-583,765.0 copies of HTLV pol gene/copies of albumin $\times 2 \times 10^{6}$ ).

HAM/TSP patients had mean values of proviral load in blood (118,839.9 vs. $65,280.2, P=0.106)$ and in saliva (1.1 vs. $0.4, P=0.154)$ higher than that found among the asymptomatic patients. After performing the quantitation of proviral load in saliva of 56 patients ( 21 had HAM/TSP), the proviral DNA was detected in 18 individuals, 9 with HAM/TSP, and 9 HTLV-1 carriers. However, the proviral load was not associated to any neurological manifestation.

Oral and dental manifestations were more frequent among HAM/TSP patients than among the HTLV-1 carriers, particularly concerning periodontal disease: tooth mobility (36\% and $28.6 \%$ ), periodontitis $(64 \%$ and $57.1 \%)$, and loss of gingival attachment $(64 \%$ and 45.7\%; Table IV). However, periodontal disease was not more frequent among those who had a detectable proviral load in their saliva.

\section{Salivary flow evaluation}

Salivary flow did not show relevant differences according to the use of medication, age, diabetes mellitus, or hypertension in both positive and negative groups. In HTLV-1 negative patients, 4 of the 6 (66.7\%) patients with PD and hyposalivation were at an advanced stage, whereas $22.7 \%$ (5/22) of the patients with normal salivary flow had PD. In the negative group, loss of gingival attachment was also more frequent among patients with hyposalivation $(66.7 \%$ vs. $18.2 \%)$. Among HTLV-1 positive patients, reduced salivary flow was not associated with periodontitis. Of those with normal and 
TABLE IV. Oral and Salivary Changes in HTLV-1-Infected Individuals According to HAM/TSP

\begin{tabular}{|c|c|c|c|c|c|}
\hline \multirow[b]{3}{*}{ Variables } & \multicolumn{5}{|c|}{ HTLV-1-infected patients } \\
\hline & \multicolumn{2}{|c|}{ No HAM/TSP } & \multicolumn{2}{|c|}{$\mathrm{HAM} / \mathrm{TSP}$} & \multirow[b]{2}{*}{$P$-value } \\
\hline & $\mathrm{n}=35$ & $\%$ & $\mathrm{n}=25$ & $\%$ & \\
\hline \multicolumn{6}{|l|}{ Salivary flow } \\
\hline Normal & 18 & 51.4 & 12 & 48.0 & \multirow[t]{2}{*}{1.000} \\
\hline Reduced & 17 & 48.6 & 13 & 52.0 & \\
\hline \multicolumn{6}{|l|}{ Dental mobility $^{\mathrm{a}}$} \\
\hline Yes & 10 & 29.4 & 9 & 39.1 & \multirow[t]{2}{*}{0.569} \\
\hline No & 24 & 70.6 & 14 & 60.9 & \\
\hline \multicolumn{6}{|l|}{ Periodontal disease $(\mathrm{PD})^{\mathrm{a}}$} \\
\hline No disease & 0 & 0.0 & 0 & 0.0 & \multirow[t]{3}{*}{0.576} \\
\hline Gingivitis & 14 & 41.2 & 7 & 30.4 & \\
\hline Periodontitis & 20 & 58.8 & 16 & 69.6 & \\
\hline \multicolumn{6}{|l|}{ Gingival attachment loss ${ }^{\text {a }}$} \\
\hline $0-3 \mathrm{~mm}$ & 18 & 52.9 & 7 & 30.4 & \multirow[t]{2}{*}{0.110} \\
\hline$>4 \mathrm{~mm}$ & 16 & 47.1 & 16 & 69.6 & \\
\hline \multicolumn{6}{|l|}{ Oral manifestations } \\
\hline Healthy oral mucosa & 20 & 57.1 & 17 & 68.0 & 0.291 \\
\hline Abscess/fistula & 2 & 5.7 & 2 & 8.0 & \\
\hline Stomatitis & 13 & 37.2 & 6 & 24.0 & \\
\hline DMTF $($ mean \pm SD) & \multicolumn{2}{|c|}{$20.64 \pm 5.6$} & \multicolumn{2}{|c|}{$21.1 \pm 5.3$} & 0.286 \\
\hline
\end{tabular}

DMFT index, decayed, missing, and filled teeth.

${ }^{a}$ The " $n$ " for analysis of these variables were respectively 57 and 28 , whereas excluded patients were edentulous.

decreased salivary flow, $65.5 \%$ and $60.7 \%$ had periodontitis, respectively.

It was only possible to perform PCR and molecular cloning successfully using the DNA from saliva cells in four (S2132, S3518, S3728, and S4192) of the eight samples. These PCR products, and the corresponding PCR products in the PBMC were cloned and a total of 79 PBMC colonies and 74 saliva colonies were obtained for plasmid DNA extraction. It was possible to detect 27 PBMC clones and 28 mouthwash clones in the analyzed colonies. The tax-LTR3' fragment obtained from these samples were submitted to "LASP HTLV-1 Automated Subtyping Tool" (http:// lasp.cpqgm.fiocruz.br) and all isolates were grouped into the Transcontinental subgroup of Cosmopolitan subtype.

When the PBMC and mouthwash virus isolates from each individual were analyzed, it was observed that there is no profile among the LTR sequences obtained from the mouthwash cells and PBMC from all the individuals by the ML and NJ analyses.
The presence of post-translational modification sites in the sequenced tax region was equivalent among the analyzed clones. The mean diversity within the PBMC and mouthwash clones from each individual was $0.005,0.003,0.008$, and 0.007 for $2,132,3,518$, 3,728 , and 4,192 patients, respectively. The panmixia probability, demonstrated by $\mathrm{p}(\mathrm{Ks})$ and $\mathrm{p}\left(\mathrm{K}^{*} \mathrm{~s}\right)$, showed no statistic significance when comparing the PBMC and mouthwash clones from individuals: 2,132, $\mathrm{p}(\mathrm{Ks})=1$ and $\mathrm{p}\left(\mathrm{K}^{*} \mathrm{~s}\right)=0.9257 ; 3,518, \mathrm{p}(\mathrm{Ks})=1$ and $\mathrm{p}\left(\mathrm{K}^{*} \mathrm{~s}\right)=1 ; \quad 3,728, \quad \mathrm{p}(\mathrm{Ks})=0.0078$ and $\mathrm{p}\left(\mathrm{K}^{*} \mathrm{~s}\right)=$ $0.0078 ;$ and 4,192, $\mathrm{p}(\mathrm{Ks})=0.4790$ and $\mathrm{p}\left(\mathrm{K}^{*} \mathrm{~s}\right)=$ 0.5355 (Table V).

\section{DISCUSSION}

HTLV-1 positive individuals had a higher frequency of oral manifestations such as dry mouth $(46.7 \%$ of positive individuals and $20 \%$ of negative ones), decreased salivary flow ( $50 \%$ and $23 \%$, respectively), attachment loss up to $4 \mathrm{~mm}$ (56.1\% and $28.6 \%$ ), tooth

TABLE V. Molecular Analysis From Four Patients With HTLV-1 Proviral Load Detectable in Mouthwash Cells

\begin{tabular}{|c|c|c|c|c|c|c|c|c|c|}
\hline \multirow[b]{2}{*}{ Sample ID } & \multicolumn{2}{|c|}{ HTLV-1 proviral load } & \multicolumn{2}{|c|}{$\begin{array}{c}\text { Number of } \\
\text { analyzed clones }\end{array}$} & \multicolumn{3}{|c|}{ Mean genetic diversity } & \multicolumn{2}{|c|}{ Panmixia probably } \\
\hline & $\begin{array}{c}\text { PBMC } \\
\left(10^{6} \text { cells }\right)\end{array}$ & $\begin{array}{l}\text { Mouthwash cells } \\
\quad\left(10^{6} \text { cells }\right)\end{array}$ & PBMC & $\begin{array}{l}\text { Mouthwash } \\
\text { cells }\end{array}$ & PBMC & $\begin{array}{l}\text { Mouthwash } \\
\text { cells }\end{array}$ & $\begin{array}{l}\text { Mouthwash } \\
\text { cells } \times \text { PBMC }\end{array}$ & $\mathrm{pKs}$ & $\mathrm{pK}^{*} \mathrm{~s}$ \\
\hline 2132 & 96196 & 210 & 03 & 05 & 0.003 & 0.007 & 0.005 & 1 & 0.9257 \\
\hline 3518 & 583765 & 1300 & 03 & 03 & 0.003 & 0.003 & 0.003 & 1 & 1 \\
\hline 3728 & 92772 & 600 & 17 & 02 & 0.007 & 0.002 & 0.012 & 0.0078 & 0.0078 \\
\hline 4192 & 197217 & 794 & 04 & 18 & 0.007 & 0.007 & 0.007 & 0.4790 & 0.5355 \\
\hline
\end{tabular}


mobility (33.3\% and $14.3 \%$ ), and periodontitis $(63.2 \%$ and $32.1 \%$ ). Seropositive individuals also presented a higher oral lesion prevalence than seronegative patients (38.3\% and $13.3 \%$, respectively) and DMFT index (21 \pm 5.4 and $16.4 \pm 7.6$, respectively). These results are in accordance with the literature [Giozza, 2006] that reports poorer oral health status in HTLV1 individuals, compared to a control group.

Individuals with HAM/TSP had a higher proviral load in the blood, as well as the number of copies of HTLV-1 DNA in saliva than the asymptomatic ones. In order to understand the possible correlation between HAM/TSP and proviral load in saliva, another study with a larger sample would be required. With regard to oral manifestation in individuals with HAM/ TSP, the data did not show significant differences when compared to asymptomatic carriers, although the group of individuals with HAM/TSP presented a higher percentage of decreased salivary flow, periodontal disease, and loss of gingival attachment when compared with asymptomatic ones. Considering salivary flow, the present study is in agreement with a previous report [Giozza, 2006] that described more pronounced hyposalivation in HAM/TSP in relation to asymptomatic carriers.

It is important to note that, comparing the relationship between reduced salivary flow and periodontal disease in HTLV-1 infected and non-infected individuals, it was observed that in the control group there was a positive association between periodontitis and loss of gingival attachment with a reduction in salivary flow. However, in the group of HTLV positive individuals, this association was not confirmed. Individuals with reduced flow and normal flow had periodontal disease in a similar proportion. The role of HTLV infection in the severity of periodontal disease needs to be clarified.

When performing the evaluation of the oral cavity of HTLV-1 positive and negative subjects, regardless of the proviral load in their saliva, an increased severity of periodontal disease in the group with HTLV-1 was clearly observed, where the majority $(63 \%)$ had periodontitis. A previous report suggested that the HTLV-1 infection may be implicated in periodontal disease due to the altered levels of cytokines [Garlet et al., 2010], which promotes an exacerbated inflammatory immune response, possibly associated with an impaired Treg activity, in response to a usual pattern of periodontal infection.

It is important to note that complaints of xerostomy may not be directly related to reduced salivary flow. A study using questionnaires and sialometry was carried out [Korn et al., 2002] and demonstrated that $46.7 \%$ of seropositive individuals reported dry mouth, while a reduction in salivary flow was found in $50 \%$. Literature reports a correlation between HTLV-1 infection and sicca syndrome (keratoconjunctivitis sicca and hyposalivation), regardless of the presence of Sjögren's syndrome [Giozza, 2006; Ferraz-Chaoui et al., 2010].
Many diseases that are associated with HTLV-1 may compromise the patients' quality of life in various ways. For this reason several indicators have been recorded in this study, including dysphagia (due to decreased salivary flow), the complaint of dry mouth, dry eyes, and depression. However, it is important to highlight the fact that oral diseases, particularly caries and periodontitis, have multifactorial causes and various aspects should be examined. When studying these pathologies, it is also important to include environmental factors, diet, habits, and the presence of systemic involvement that may contribute to the development of oral disease [Peres et al., 2003; Ragghianti et al., 2004; Gushi et al., 2005].

In the present research, the prevalence of HTLV-1 was higher in people with low levels of education and low income, corroborating previous reports [Dourado et al., 2003; Mota et al., 2006]. In addition, literature has shown that income and educational level are other aspects that must be considered when evaluating caries and periodontal disease [Jovino-Silveira et al., 2005]. As with HTLV-1, the prevalence of oral diseases is inversely proportional in individuals with lower educational levels and lower income. Thus, oral manifestations in patients with HTLV-1 should be analyzed with caution, taking into account the variables involved in order to establish any causal relationship.

The presence of provirus in saliva seems to be related to a high level of proviral load in peripheral blood. This finding may mean that a high proviral load may potentially induce systemic inflammatory manifestations as occurs in HAM/TSP. On the other hand, only one individual who had a proviral load detected in mouthwash cells presented lower levels of PBMC proviral load. Because of the fact that studies evaluating the antibody response in saliva suggest a weak immune response to HTLV-1 in saliva, which could be an important factor in the increase in the proviral load [Belec et al., 1996], it is possible to infer that the proviral load detected in the saliva could be the result of an immune system balance in this corporeal fluid. This possibility highlights the risk of the presence of a few infected cells in the saliva, an important via of transmission, without any sign of detection through proviral load, when the immune response is able to control the virus spread.

As regards intra-host variations, the analysis included clones from three levels of proviral load, and no difference was identified. This result confirms the need to perform a similar study with a longer virus genomic fragment in order to obtain more information, and this will probably detect some variation when comparing individuals. The low genetic diversity suggests, unlike HIV, that the HTLV-1 is a long latency virus, spreading slowly in infected patients due to the slow replication cycle.

The panmixia probability showed that the PBMC and mouthwash clones from individuals were from a common ancestor, suggesting that there is no mutational profile determining the HTLV-1-infected cells 
in mouthwash. HTLV-1 in saliva is probably a result of the infiltration of lymphocytes by oral mucosa lesions, and high levels of proviral load in peripheral blood.

HTLV-1 transmission occurs mainly by cell-to-cell contact or cell-to-cell fusion (also named syncytium formation). The gp46 protein codified by the envelop gene is responsible for the main antibody response against HTLV-1. Antibody IgG anti-gp46 peptides are capable of neutralizing the syncytium formation therefore HTLV-1 transmission from person to person by kissing or sharing tableware, if it occurs, seems rare.

In conclusion, this study found that HTLV-1 patients have poorer oral health status, characterized by decreased salivary flow, advanced periodontitis, and loss of gingival attachment when compared to seronegative individuals. A weak positive correlation between blood and saliva proviral loads was observed and the amount of virus detected in the saliva was lower than that detected in the blood. The mean values of proviral load in blood and saliva in patients with HAM/TSP was greater than those in HTLV-1 carriers. The HTLV-1 molecular analysis from PBMC and saliva specimens suggests that the HTLV-1 in saliva is due to lymphocyte infiltration from peripheral blood.

HAM/TSP patients had a higher frequency of oral disease in relation to asymptomatic individuals. A direct relationship between proviral load in saliva and oral manifestations was also observed. Another study with a large sample, including a salivary gland biopsy, would be necessary not only to obtain the diagnosis of Sjögren's syndrome, but also to investigate the possible relationship between glandular lymphocytic infiltratation and hyposalivation. Histopathological examination, with supplementary immunohistochemistry, would be helpful in order to understand the role of the HTLV in the pathogenesis of sialadenitis and periodontal disease better. The fact that lymphocytes are scarce in the saliva, but are present in glandular inflammation should also be investigated. The proviral load in the salivary gland may be higher than in saliva.

\section{ACKNOWLEDGMENTS}

The bioinformatic analyses were performed at the Bioinformatics Unit of the LASP/CPqGM/FIOCRUZ, with the financial support of FAPESB (grant 303/03) and the Brazilian Ministry of Health (306/04 and 307/ 04). The authors are grateful to Noilson Lázaro de Souza Gonçalves for his technical assistance. The authors thank the Program for Technological Development in Tools for Health-PDTIS/FIOCRUZ for the use of its facilities.

\section{REFERENCES}

Alcantara LCJ, Oliveira T, Gordon M, Pybus O, Mascarenhas RE, Seixas MO, Gonçalves M, Hlela C, Cassol S, Galvão-Castro B.
2006. Tracing the origin of Brazilian HTLV-1 as determined by analysis of host and viral genes. AIDS 20:780-782.

Belec L, Jean Georges A, Hallouin MC, Si Mohamed A, MorandJoubert L, Georges-Courbot MC. 1996. Human T cell Lymphotropic virus type I excretion and specific antibody response in paired saliva and servicovaginal secretions. AIDS Res Hum Retroviruses 12:157-167.

Catalan-Soares BC, Proietti FA, Carneiro- Proietti ABF. 2001. Os vírus linfotrópicos de células T humanos (HTLV) na última década (1990-2000): Aspectos epidemiológicos. Rev Bras Epidemiol 4:81-95.

Cruz BA, Catalan-Soares B, Proietti F. 2005. Manifestacões reumáticas associadas ao vírus linfotrófico humano de células $\mathrm{T}$ do tipo I (HTLV-I). Rev Bras Reumatol 45:71-77.

Dehee A, Cesaire R, Desire N, Lézin A, Bourdonné O, Béra O, Plumelle Y, Smadja D, Nicolas JC. 2002. Quantitation of HTLV-I proviral load by a TaqMan real-time PCR assay. J Virol Methods 102:37-51.

Dourado I, Alcantara LCJ, Barreto ML, Teixeira MG, Galvão-Castro B. 2003. HTLV-I in the general population of Salvador, Brazil: A city with African ethnic and sociodemographic characteristics. J Acquir Immune Defic Syndr 34:527-531.

Ferraz-Chaoui AK, Atta AM, Atta ML, Galvão-Castro B, Santiago MB. 2010. Study of autoantibodies in patients with keratoconjuctivitis sicca infected by the human $\mathrm{T}$ cell lymphotropic vírus type 1. Rheumatol Int 30:775-778.

Galvão-Castro B, Loures L, Rodriques LG, Sereno A, Ferreira Junior OC, Franco LG, Muller M, Sampaio DA, Santana A, Passos LM, Proietti F. 1997. Distribution of human T-lymphotropic virus type I among blood donors: A Nationwide Brazilian study. Transfusion 37:242-243.

Garlet GP, Giozza SP, Silveira EM, Claudino M, Santos SB, AvilaCampos MJ, Martins W Jr., Cardoso CR, Trombone AP, Campanelli AP, Carvalho EM, Silva JS. 2010. Association of human T lymphotropic virus 1 amplification of periodontitis severity with altered cytokine expression in response to a standard periodontopathogen infection. Clin Infect Dis 50:11-18.

Gessain A, Barin F, Vernant JC, Gout O, Maurs L, Calender A, De Thé G. 1985. Antibodies to human T lymphotropic virus typeI in patients with tropical spastic paraparesis. Lancet 2:407-410.

Giozza SP. 2006. Manifestações orais: Aspectos clínicos e imunológicos em indivíduos portadores de HTLV-1. 2006. 117f. Thesis. Instituto de Ciências da Saúde, Universidade Federal da Bahia, Salvador, Bahia, Brazil.

Gushi LL, Soares MC, Forni TIB, Vieira V, Wada RS, Sousa MLR. 2005. Cárie dentária entre os adolescentes e sua relação com as variáveis sócio-econômicas. J Appl Oral Sci 13:305-311.

Haddad SK. 2004. Caracterização molecular de isolados brasileiros do vírus linfotrópico de células T humanas do tipo 1 (HTLV-1) Thesis. Faculdade de Medicina, Universidade de São Paulo, São Paulo.

Jorge AOC. 1998. Regulação e controle da microbiota bucal. In: Jorge AOC, editor. Microbiologia bucal. São Paulo: Santos, pp 21-29.

Jovino-Silveira RC, Caldas Ade F, Jr., de Souza EH, Gusmão ES. 2005. Primary reason for tooth extraction in a Brazilian adult population. Oral Health Prev Dent 3:151-157.

Korn GP, Pupo DB, Quedas A, Filho IV. 2002. Correlação entre o grau de xerostomia e o resultado da sialometria em pacientes com síndrome de Sjogren. Rev Bras Otorrinolaringol 68:624-628.

Krasse B. 1998. Risco de cárie: Um guia prático para avaliação e controle. 2nd edition. São Paulo: Quintessence Ltda, p 113.

Kumar S, Tamura K, Nei M. 1994. MEGA: Molecular evolutionary genetics analysis software for microcomputers. Comput Appl Biosci 10:189-191.

La Grenade L, Manns A, Fletcher V, Derm D, Carberry C, Hanchard B, Maloney EM, Cranston B, Williams NP, Wilks R, Kang EC, Blattner WA. 1998. Clinical, pathologic, and immunologic features of human T-lymphotrophic virus type I-associated infective dermatitis in children. Arch Dermatol 134:439-444.

Mariette X, Agbalika F, Zucker-Franklin D, Clerc D, Janin A, Cherot P, Brouet JC. 2000. Detection of the tax gene of HTLV-I in labial salivary glands from patients with Sjogren's syndrome and other diseases of the oral cavity. Clin Exp Rheumatol 18 341-347.

Mochizuki M, Ono A, Ikeda E, Hikita N, Watanabe T, Yamaguchi K, Sagawa K, Ito K. 1996. HTLV-1 uveitis. J Acquir Immune Defic Syndr Human Retrovirol 13:S50-S56. 
Mota A, Nunes C, Melo A, Romeo M, Boa-Sorte N, Dourado I, Alcântara LC, Galvão-Castro BA. 2006. Case-control study of HTLV-infection among blood donors in Salvador, Bahia, BrazilAssociated risk factors and trend towards declining prevalence. Rev Bras Hematol Hemoter 28:120-126.

Nakamura H, Kawakami A, Tominaga M, Hida A, Yamasaki S, Migita K, Kawabe Y, Nakamura T, Eguchi K. 2000. Relationship between Sjogren's syndrome and human T-lymphotropic virus type I infection: Follow-up study of 83 patients. J Lab Clin Med 135:139-144.

Nicholas KB, Nicholas HBJ, Deerfield DW. 1997. GeneDoc: Analysis and visualization of genetic variation. EMBNEW News 4:14.

Osame M. 1990. Review of WHO Kagoshima meeting and diagnostic guidelines for HAM/TSP. In: Blattner W, editor. Human Retrovirology HTLV. 1st edition. New York: Raven Press, pp 191-197.

Osame M, Usuku J, Izumo S, Ijichi N, Amitani H, Igata A, Matsumoto M, Tara M. 1985. HTLV-1 associated myelopathy: A new clinical entity. Lancet 1:1031-1032 (definir).

Peres MA, LaTorre MRDO, Sheiham A, Peres KG, Barros FC, Hernandez PG, Maas AMN, Romano AR, Victora CG. 2003 . Determinantes sociais e biológicos da cárie dentária em crianças de 6 anos de idade: Um estudo transversal aninhado numa coorte de nascidos vivos no Sul do Brasil. Rev Bras Epidemiol 6:293-306.

Poiez BF, Ruscetti FW, Gazder AF, Bunn PA, Minna JD, Gallo RC. 1980. Detection and isolation of type $\mathrm{C}$ retrovirus particles from fresh and cultured lymphocytes of a patient with cutaneous T-cell lymphoma. Proc Natl Acad Sci USA 77:7415-7419.

Posada D, Crandall KA. 1998. MODELTEST: Testing the model of DNA substitution. Bioinformatics 14:817-818.

Proietti FA, Carneiro-Proietti AB, Catalan-Soares BC, Murphy EL. 2005. Global epidemiology of HTLV-I infection and associated diseases. Oncogene 24:6058-6068.
Ragghianti MS, Greghi SLA, Lauris JRP, Sant'ana ACP, Passanezi E. 2004. Influência da idade, sexo, placa bacteriana e fumo nas condições periodontais em uma população de Bauru, Brasil. J Appl Oral Sci 12:273-279.

Swofford DL. 1998. PAUP*: Phylogenetic analysis using parsimony (and other methods). Version 4.0b5. Sinauer Associates, Sunderland, MA.

Tangy F, Ossondo M, Vernant JC. 1999. Human T-cell leukemia vírus type I expresssion in salivary glands of infected patients. $J$ Infect Dis 179:497-502.

Terada K, Katamine S, Eguchi K, Moriuchi R, Kita M, Shimada H, Yamashita I, Iwata K, Tsuji Y, Nagataki S. 1994. Prevalence of serum and salivary antibodies to HTLV-1 in Sjögren's syndrome. Lancet 344:1116-1119.

Thompson JD, Gibson TJ, Plewniak F, Jeanmougin F, Higgins DG 1997. The CLUSTAL_X Windows interface: Flexible strategies for multiple sequence alignment aided by quality analysis tools. Nucleic Acids Res 25:4876-4882.

Thylstrup A, Fejerskov O. 2001. Cariologia clínica. 3rd edition. São Paulo: Santos, p 421.

WHO (World Health Organization). 1999. Levantamentos básicos em Saúde bucal. 4th edition. São Paulo: Santos, p 68.

Yakova M, Lézin A, Dantin F, Lagathu G, Olindo S, Jean-Baptiste G, Arfi S, Césaire R. 2005. Increased proviral load in HTLV-1 infected patients with rheumatoid arthritis or connective tissue disease. Retrovirology 2:1-9.

Yamamoto T, Terada K, Nishida N, Moriuch R, Shirabe S, Nakamura T, Tsuji Y, Miyamoto T, Katamine S. 1995. Inhibitory activity in saliva of cell-to-cell transmission of human T-cell lymphotropic virus type 1 in vitro: Evaluation of saliva as an alternative source of transmission. J Clin Microbiol 33:1510 1515 . 